\title{
SUBTITUSI PARSIAL AGREGAT HALUS DENGAN BOTTOM ASH PADA PEMBUATAN BATA SEMEN
}

\author{
Mufti Amir Sultan ${ }^{* 1}$ Imran $^{1}$ dan Rofika Sakti ${ }^{2}$ \\ ${ }^{1}$ Dosen / Program Studi Teknik Sipil/ Universitas Khairun \\ 2Mahasiswa / Program Studi Teknik Sipil/ Universitas Khairun \\ Korespondensi: muftiasltn@unkhair.ac.id
}

\begin{abstract}
The Tidore Islands Municipal Steam Power Plant uses coal as fuel to generate electricity. Handling of coal waste in the Rum PLTU is done by storing it on empty land so that it is not effective because it can be potentially dangerous for the environment and surrounding communities. Therefore, it is important to use coal waste. One of them is in the construction field such as in the manufacture of cement bricks. The purpose of this study is to determine the level of water absorption and compressive strength of cement brick using bottom ash base material. Water absorption testing is carried out when the specimen has been immersed for 28 days. The test object is weighed in the SSD state and then inserted into the oven and left for 24 hours. Then the test object is left idle and then weighed. Testing of compressive strength was carried out when the specimen was 28 days old. The results of the study show that the absorption rate of cement brick is increasing when bottom ash is added. Meanwhile, for compressive strength, the cement brick has decreased
\end{abstract}

Kata Kunci : bottom ash, cement brick, PLTU, Rum, Tidore

\section{PENDAHULUAN}

PLTU Rum yang terletak pada wilayah Kota Tidore Kepulauan memanfaatkan batu bara sebagai bahan bakar untuk menghasilkan energi listrik. Penanganan limbah batu bara pada PLTU Rum tersebut dilakukan dengan cara menimbunnya di lahan yang kosong sehingga masih tidak efektif karena dapat berpotensi bahaya bagi lingkugan dan masyarakat sekitar. Oleh karena itu penting adanya pemanfaatan limbah batu bara, salah satunya yaitu pada bidang konstruksi seperti pada pembuatan bata semen, yang umum dipakai oleh masyarakat setempat sebagai bahan bangunan pasangan dinding.

Batubara dalam penggunaannya sebagai sumber bahan bakar untuk PLTU Rum menghasilkan limbah pembakaran berupa abu terbang (fly ash) dan abu dasar (bottom ash). Mengingat penanganan limbah bottom ash umumnya di PLTU Rum hanya ditimbun atau ditumpuk di lahan kosong di dalam area PLTU dan belum banyak alternatif untuk mengolah dan memanfaatkannya, sedangkan pemanfaatan limbah fly ash sudah banyak alternatif yang dihasilkan, salah satunya menjadi bahan subtitusi semen.

Beberapa penelitian pemanfaatan limbah sisa pembakaran batu bara diantaranya : Penelitian dengan memanfaatkan abu terbang (fly ash) terhadap kuat tarik dan kuat tekan bata ringan, dapat disimpulkan bahwa dengan penambahan fly ash sebesar $30 \%$ dapat menghasilkan bata ringan lebih baik dibandingkan tanpa penambahan fly ash [1]. Penelitian dengan menggunakan abu batu bara sebagai material pembentuk bata abu-abu, menghasilkan bahwa abu batu bara terbang (fly ash), merupakan alternatif yang lebih baik ketimbang menggunakan tanah liat yang dibakar secara konvensional terutama dari segi struktural, fungsional dan aspek ekonominya. Dengan memanfaatkan aspek ini, maka bisa mengubah sampah menjadi kekayaan [2]. Penggunaan fly ash dan bottom ash sebagai bahan komposit bata beton, menyatakan bahwa limbah batu bara (bottom ash dan fly ash) dapat dimanfaatkan sebagai bahan agregat dalam 
pembuatan bata beton ringan yang kualitasnya memenuhi syarat minimal untuk konstruksi pasangan dinding bangunan rumah [3]. Penelitian dengan menggunakan bottom ash sebagai subtitusi tanah liat pada campuran bata, dari hasil penelitian bahwa penggunaan bottom ash sebagai pengganti tanah liat dengan prosentase maksimum $45 \%$ dapat menghasilkan batu bata yang memiliki kuat tekan yang sama dengan atau lebih dari batu bata yang menggunakan tanah liat 100\% [4].

Penggunaan limbah batu bara (fly ash) sebagai bahan tambah pasa proses pembuatan bata ringan. Hasil penelitian menunjukkan bahwa dengan penambahan fly ash dapat memperbaiki kinerjia penyerapan dan kuat tekan bata semen [5].

Pembuatan bata ringan dengan menggunakan campuran abu terbang dari PLTU Asam-asam, diperoleh bata dengan tingkat mutu IV sesuai SNI dan berat $<1800$ $\mathrm{kg} / \mathrm{m}^{3}$, sehingga termasuk kategori bata ringan [6].

\section{TINJAUAN PUSTAKA}

\subsection{Mortar}

Mortar didefenisikan sebagai campuran material yang terdiri dari agregat halus (pasir), bahan perekat (tanah liat, kapur, semen portland) dan air dengan komposisi tertentu [7]. Mortar memiliki nilai penyusutan yang relatif kecil. Kekuatan geser mortar harus dapat memikul gaya-gaya yang bekerja pada mortar serta mortar harus tahan terhadap penyerapan air, karena mortar akan mengeras dengan cepat apabila penyerapan air pada mortar terlalu besar.

Mortar dicetak dengan proses pemadatan menjadi bentuk persegi atau segi banyak dengan ukuran dan persyaratan tertentu kemudian untuk proses pengerasannya, mortar ditempatkan pada tempat yang tidak terkena sinar matahari secara langsung maupun hujan.

\subsection{Spesifikasi Mortar}

Spesifikasi mortar harus memenuhi ketentuan persyaratan bahan dan pengujian. Spesifikasi mortar terdiri dari dua, yaitu sebagai berikut : [8]
a. Spesifikasi proporsi
b. Spesifikasi sifat

\subsection{Bata Semen}

Bata pres dibuat dari campuran semen dan pasir atau abu batu. Ada yang dibuat secara manual (menggunakan tangan), ada juga yang menggunakan mesin. Perbedannya dapat dilihat pada kepadatan permukaan bata semennya.

Batu cetak beton (concrete block) adalah komponen bangunan yang dibuat dari campuran semen portland atau pozzolan, pasir dan air dan atau tanpa bahan tambahan lainnya (additive) dicetak sedemikian rupa hingga memenuhi syarat dan dapat digunakan sebagai bahan untuk pasangan dinding [9].

Bata semen tidak dibakar ini dari tras dan kapur, kadang-kadang juga dengan sedikit semen portland, sudah mulai dikenal oleh masyarakat sebagai bahan bangunan dan sudah pula dipakai untuk pembuatan rumah dan gedung [10].

\section{METODE PENELITIAN 3.1 Benda Uji}

Tabel 1. Komposisi dan jumlah benda uji, pengujian pada umur 28 hari

\begin{tabular}{c|c|c}
\hline Benda Uji & $\begin{array}{c}\text { Bottom ash } \\
(\%)\end{array}$ & Jumlah (buah) \\
\hline MN (Normal) & 0 & 24 \\
\hline MB-1 & 10 & 24 \\
\hline MB-2 & 20 & 24 \\
\hline MB-3 & 30 & 24 \\
\hline MB-4 & 40 & 24 \\
\hline MB-5 & 50 & 24 \\
\hline MB-10 & 100 & 24 \\
\hline \multicolumn{2}{c|}{ Jumlah } & 168 \\
\hline
\end{tabular}

Pembuatan benda uji mortar bata semen sebanyak 168 sampel dengan masing-masing benda uji berbentuk kubus berukuran $5 \mathrm{~cm}$ x 5 $\mathrm{cm} \times 5 \mathrm{~cm}$, dengan menggunakan campuran bata semen yang mengacu pada SNI 03-6825-2002 tentang metode pengujian kekuatan tekan mortar semen portland untuk pekerjaan sipil. Komposisi benda uji untuk pengujin kuat tekan bata semen ditunjukan seperti pada Tabel 1.

\subsection{Pengujian Kuat Tekan}

Setelah benda uji disimpan selama 24 jam, selanjutnya benda uji direndam selama 28 (dua 
puluh delapan) hari, setelah itu dilakukan pengujian kuat tekan dan penyerapan air benda uji dengan waktu curing/perendaman yang telah ditentukan. Pengujian kuat tekan bata semen dilakukan dengan mengacu pada SNI 03-6825-2002 tentang metode pengujian kekuatan tekan mortar semen portland untuk pekerjaan sipil. Rumus yang digunakan untuk perhitungan kekuatan tekan mortar adalah sebagai berikut :

$f^{\prime} c=\frac{\text { Pmaks }}{A}$.

Di mana :

f'c : kekuatan tekan mortar, $\mathrm{MPa}$

Pmaks : gaya tekan maksimum, $\mathrm{N}$

A : luas penampang banda uji, $\mathrm{mm}^{2}$

Kemudian untuk pengujian penyerapan air pada bata semen mengacu pada SNI 03-0349-1989 dengan rumus sebagai berukut :

Penyerapan $=\frac{W w-W d r y}{W d r y} \times 100 \%$

Di mana :

$\mathrm{W}_{\mathrm{w}} \quad$ : berat mortar basah $(\mathrm{kg})$

$\mathrm{W}_{\text {dry }} \quad$ : berat mortar kering $(\mathrm{kg})$

\section{HASIL DAN PEMBAHASAN}

4.1 Unsur Bottom Ash

Hasil pengujian senyawa kimia XRF pada limbah batu bara (bottom ash) dapat dilihat pada Gambar 1.

Dari Gambar 1 dapat dilihat bahwa senyawa terbesar yang terkandung pada limbah batubara (bottom ash) adalah $\mathrm{Fe}$ (ferrum) sebesar 53,34\%, Ca (kalsium) sebesar 18,2\% dan Si (silikon) sebesar 14,5\%. Perbandingan senyawa kimia agregat halus (pasir) dan limbah batu bara (bottom ash) dapat dilihat pada Tabel 2.

Menurut penelitian sebelumnya [11] yaitu senyawa kimia yang terkandung pada limbah batu bara (bottom ash) presentasenya hampir sama dengan senyawa kimia yang terkandung pada agregat halus (pasir). Pada Tabel 2 dapat dilihat presentase senyawa agregat halus (pasir) dan limbah batu bara (bottom ash) memiliki kesamaan.

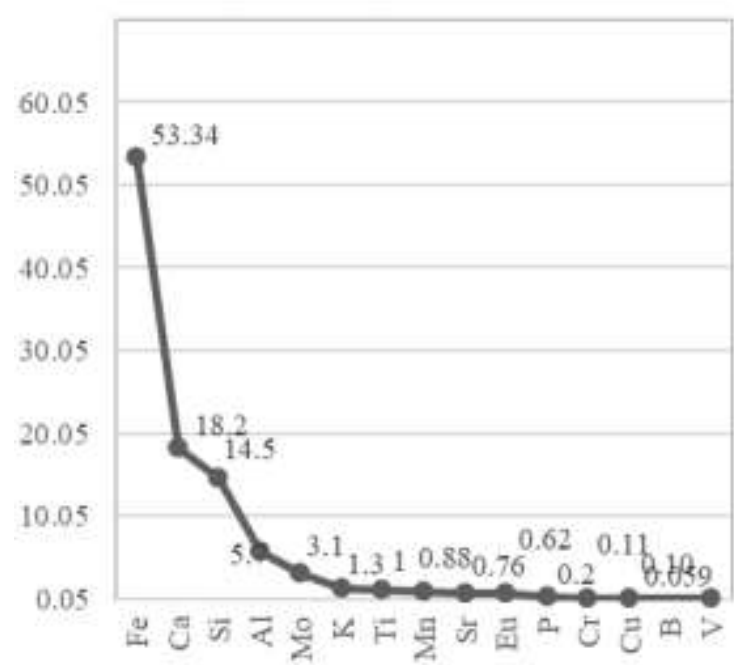

Gambar 1 Kandungan senyawa kimia bottom ash (kadar dalam \%)

Tabel 2. Hasil uji XRF agregat halus dan bottom ash

\begin{tabular}{c|c|c}
\hline Senyawa Kimia & Pasir $(\%)$ & Bottom ash $(\%)$ \\
\hline $\mathrm{Fe}$ (Ferrum) & 44.1 & 53.34 \\
\hline $\mathrm{Ca}$ (Kalsium) & 19.7 & 18.2 \\
\hline $\mathrm{Si}$ (Silika) & 19.4 & 14.5 \\
\hline $\mathrm{Al}$ (Aluminium) & 6.9 & 5.7 \\
\hline $\mathrm{Mo}$ (Molibden) & - & 3.1 \\
\hline $\mathrm{K}$ (Kalium) & 2.04 & 1.3 \\
\hline $\mathrm{Ti}$ (Titanium) & 1.87 & 1.0 \\
\hline $\mathrm{Mn}$ (Mangan) & 0.84 & 0.88 \\
\hline $\mathrm{Sr}$ (Strontium) & 1.5 & 0.76 \\
\hline $\mathrm{Eu}$ (Europium) & 0.3 & 0.62 \\
\hline $\mathrm{P}$ (Fosfor) & 0.51 & 0.2 \\
\hline $\mathrm{Cr}$ (Crom) & 0.082 & 0.11 \\
\hline $\mathrm{Cu}$ (Cuprum) & 0.37 & 0.10 \\
\hline $\mathrm{Ba}$ (Barium) & 0.4 & 0.1 \\
\hline $\mathrm{V}$ (Vanadium) & 0.13 & 0.059 \\
\hline
\end{tabular}

\subsection{Penyerapan bata semen}

Pengujian terhadap penyerapan batas semen menggunakan variasi limbah batu bara (bottom ash) sebagai bahan subtitusi dari agregat halus (pasir). Limbah batu bara (bottom ash) berpengaruh pada nilai penyerapan bata semen, dimana pada setiap variasi penambahan 
limbah batu bara (bottom ash). Dari hasil pengujian penyerapan pada bata semen dengan atau tanpa variasi limbah batu bara (bottom ash) dapat dilihat pada grafik seperti pada Gambar 2.

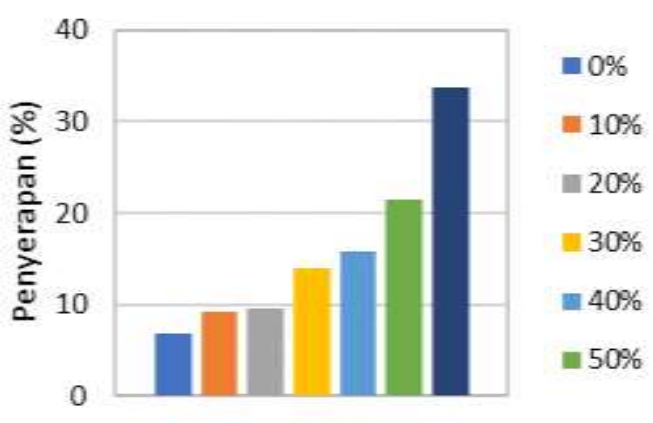

Gambar 2. Penyerapan bata semen dengan variasi penggantian bottom ash terhadap agregat halus (pasir)

Pada Gambar 2 diatas menunjukkan kenaikan presentase penyerapan pada setiap penambahan limbah batu bara (bottom ash). Hal dikarenakan daya serap yang begitu besar terjadi saat penambahan variasi terhadap bottom ash pada masing-masing bata semen. Selain itu dilihat dari karakteristik limbah batu bara (bottom ash) memiliki bentuk yang ringan dan sedikit besar dari agregat halus (pasir) serta memiliki banyak lubang-lubang kecil yang mengakibatkan benda uji tidak terlalu padat sehingga air dapat dengan mudah masuk pada lubang-lubang kecil yang terbentuk dan menyebabkan tingkat penyerapannya semakin besar.

Berdasarkan Gambar 2 juga dapat diketahui perbedaan penyerapan pada bata semen normal dan bata semen yang menggunakan variasi limbah batu bara (bottom $a s h$ ). Dimana pada penelitian ini penyerapan air yang paling besar terjadi pada variasi $100 \%$ penambahan limbah batu bara (bottom ash) yaitu sebesar $33.762 \%$, nilai penyerapan tersebut diatas lebih besar dari pada nilai penyerapan pada variasi yang lain. Menurut SNI 03-0349-1989 penyerapan air maksimal untuk mutu I (satu) adalah $25 \%$ dan mutu II (dua) adalah $35 \%$. Penyerapan terbesar masuk pada variasi penambahan batu bara (bottom ash) $100 \%$ sebesar $33.762 \%$ sehingga pengujian penyerapan air pada bata semen dikategorikan masuk mutu II (dua). Sehingga dengan ketentuan SNI 03-0349-1989 apabila dibandingkan dengan hasil pada penelitian maka bata semen dengan bahan dasar bottom ash dikatakan memenuhi syarat kelayakan.

\subsection{Kuat tekan bata semen}

Hasil pengujian kekuatan tekan pada paving block dengan atau tanpa variasi limbah batu bara (bottom ash) dapat dilihat pada grafik seperti pada Gambar 3.

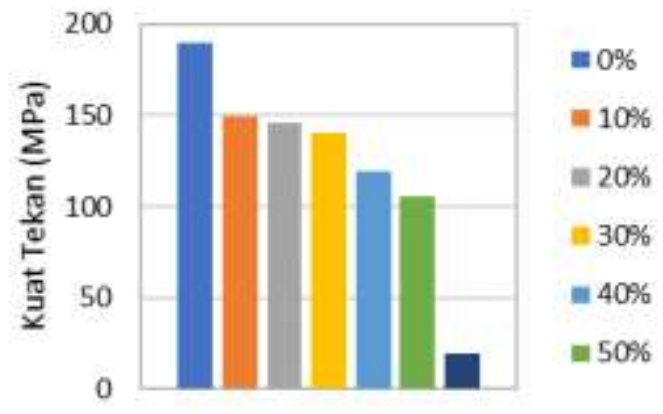

Gambar 3. Kuat tekan bata semen dengan variasi penggantian bottom ash terhadap agregat halus (pasir)

Kekuatan tekan paling besar terjadi pada variasi normal yaitu $190.282 \mathrm{~kg} / \mathrm{cm}^{2}$ dan mulai mengalami penurunan pada masing-masing penambahan variasi limbah batu bara (bottom ash). Hal ini dikarenakan pada pencampuran pembuatan benda uji, untuk presentase penambahan agregat halus (pasir) semakin berkurang kemudian presentase penambahan limbah batu bara (bottom ash) semakin bertambah dan presentase penambahan semen tetap, sehingga mengakibatkan jumlah semen tidak proporsional terhadap jumlah agregat halus (pasir) dan limbah batu bara (bottom ash). Sedangkan semen merupakan unsur pengikat dalam pencampuran bata semen, sehingga semakin bertambah presentase limbah batu bara (bottom ash) dapat menurunkan kekuatan tekan bata semen karena daya ikat dari semen tidak mampu mengikat pencampuran dengan baik.

Selain tidak proporsional presentase semen terhadap agregat halus (pasir) dan limbah batu bara (bottom ash), faktor pemicu turunnya tingkat kekuatan tekan terhadap bata semen juga berkaitan dengan pengujian karakteristik agregat terhadap penyerapan dan kadar air pada limbah batu bara (bottom ash) dimana tingkat penyerapan dan kadar air rata-ratanya sangat besar dan tidak memenuhi spesifikasi standar [11-13]. 
Bentuk butir dari limbah batu bara (bottom ash) juga lebih besar dari agregat halus (pasir) sehingga tingkat kepadatan bata semen juga berkurang, apabila semakin besar presentase variasi limbah batu bara (bottom ash) maka semakin banyak pori-pori yang terdapat pada bata semen sehingga mengakibatkan penurunan kekuatan tekan bata semen pada penambahan presentase variasi limbah batu bara (bottom ash). Selain bentuk butir limbah batu bara (bottom ash) yang lebih besar dari agregat halus (pasir), limbah batu bara (bottom ash) juga memilik berat yang lebih ringan dari agregat halus (pasir) sehingga pada saat penambahan presentase limbah batu bara (bottom ash) terhadap berat pasir, volumenya lebih besar dibandingkan pencampuran tanpa presentase limbah batu bara (bottom ash), hal ini menyebabkan presentase semen tidak proposional sehingga semen tidak mampu mengikat pencampuran dengan baik.

\subsection{Klasifikasi bata semen}

Tabel 2. Klasifikasi bata berdasarkan SNI 03-0349-1989

\begin{tabular}{|c|c|c|c|c|c|}
\hline \multirow{2}{*}{$\begin{array}{c}\text { Variasi } \\
\text { Bottom } \\
\text { Ash } \\
(\%)\end{array}$} & \multicolumn{2}{|c|}{$\begin{array}{c}\text { Kuat Tekan } \\
\left(\mathrm{kg} / \mathrm{cm}^{2}\right)\end{array}$} & \multicolumn{2}{|c|}{$\begin{array}{c}\text { Penyerapan } \\
(\%)\end{array}$} & \multirow{2}{*}{$\begin{array}{c}\text { Tingkat } \\
\text { Mutu }\end{array}$} \\
\hline & $\begin{array}{c}\text { Hasil } \\
\text { Uji }\end{array}$ & $\begin{array}{l}\text { Syarat } \\
\text { Fisis }\end{array}$ & $\begin{array}{l}\text { Hasil } \\
\text { Uji }\end{array}$ & $\begin{array}{c}\text { Syarat } \\
\text { Fisis }\end{array}$ & \\
\hline $0 \%$ & 190.282 & 100 & 6.706 & 25 & I \\
\hline $10 \%$ & 149.507 & 100 & 9.199 & 25 & I \\
\hline $20 \%$ & 146.109 & 100 & 9.555 & 25 & I \\
\hline $30 \%$ & 139.993 & 100 & 13.881 & 25 & I \\
\hline $40 \%$ & 119.606 & 100 & 15.859 & 25 & I \\
\hline $50 \%$ & 105.335 & 100 & 21.547 & 25 & I \\
\hline $100 \%$ & 19.028 & 25 & 33.762 & - & - \\
\hline
\end{tabular}

Dari hasil pengujian pada penelitian ini baik pada pengujian penyerapan bata semen atau pada pengujian kekuatan tekan bata semen dapat diketahui kelas mutu dari bata semen dengan syarat-syarat fisis yang mengacu pada SNI 03-0349-1989. Karakteristik bata semen dengan syarat fisis dapat dilihat pada Tabel 3.

Pada pengujian penyerapan air bata semen menunjukkan kemampuan bata semen dalam menyerap air. Akan tetapi apabila semakin besar tingkat penyerapan bata semen maka akan berbanding terbalik dengan kemampuannya menahan beban, dimana kekuatan tekannya akan mengalami penurunan.
Dari hasil Tabel 3 dengan presentase variasi penambahan limbah batubara (bottom ash) dapat menunjukan bahwa bata semen dengan variasi normal memiliki nilai kuat tekan terbesar, akan tetapi pada variasi penambahan limbah batubara (bottom ash) dari 10\% sampai $50 \%$ masih dikategorikan masuk pada mutu I.

\section{KESIMPULAN DAN SARAN}

Berdasarkan hasil penelitian yang telah dilakukan, maka dapat disimpulkan sebagai berikut :

a. Limbah batu bara (bottom ash) memiliki pengaruh yang begitu besar terhadap penyerapan air pada bata semen. Hal ini dapat diketahui dengan adanya kenaikan presentase penyerapan air pada setiap penambahan variasi limbah batu bara (bottom ash), dikarenakan bentuk butiran dari limbah batu bara (bottom ash) yang begitu ringan dan ukuran butirnya yang lebih besar dari pasir sehingga mengakibatka terdapat banyak pori-pori pada bata semen.

b. Penurunan presentase kuat tekan pada bata semen dengan penambahan variasi limbah batu bara (bottom ash). Hal ini dikarenakan ukuran butir limbah batu bara (bottom ash) lebih besar dan ringan dari pasir sehingga penggunaan limbah batu bara (bottom ash) lebih banyak sehingga semen yang digunakan tidak mampu mengikat dengan baik. Selain itu semen yang digunakan juga memiliki variasi presentase yang tetap sehingga tidak proporsi dengan variasi presentase limbah batu bara (bottom ash).

\section{DAFTAR PUSTAKA}

[1] Karijanto, M.A., Wijaya, A.R., dan Sugiharto, H., Pengaruh Penambahan Fly Ash Terhadap Kuat Tekan dan Kuat Tarik Perekat Bata Ringan, Dimensi Pratama Teknik Sipil 2(2), 2013: 1-8.

[2] Eisenring, M.P., Abu Batubara Sebuah Konsep Inovatif Bagi Produksi Bata Abu-abu Untuk Memperoleh Kekuatan Tinggi dan Aman Terhadap Lingkungan, Majalah Ilmiah Mektek 15(1), 2013: 20-29.

[3] Ola, A.L., dan Silaban, D.P., Komposit Bata Beton Ringan dari Fly Ash dan Bottom Ash Limbah Batubara Minyak Nabati, Jurnal Riset Teknologi Industri 12(1), 2018: 47-55.

[4] Suseno, H., Prastumi, P., Susanti, L., dan Setyowulan, D., Pengaruh Penggunaan 
Bottom Ash Sebagai Pengganti Tanah Liat pada Campuran Bata Terhadap Kuat Tekan Bata, Jurnal Rekayasa Sipil 6(3), 2012: 264 271.

[5] Kabir, D., Imran, I., dan Sultan, M.A., Penggunan Fly Ash Sebagai Bahan Tambah pada Proses Pembuatan Mortar dengan Bahan Dasar Pasir Apung, Techno 7(2), 2018: 157 164.

[6] Haryanti, N.I., Kuat tekan bata ringan dengan bahan campuran abu terbang PLTU asam-asam Kalimantan Selatan, Jurnal Fisika Flux 12(1), 2015: 20 - 30.

[7] SNI-03-6825, Metode Pengujian Kekuatan Tekan Mortar Semen Portland Untuk Pekerjaan Sipil, Jakarta, 2002: 13.

[8] SNI-03-6882, Spesifikasi Mortar Untuk Pekerjaan Unit Pasangan, Jakarta, 2014: 43.
[9] SNI-03-0349, Bata Beton Untuk Pasangan Dinding, Jakarta, 1989: 10.

[10] Darmono., Tinjauan Kualitas Hasil Wirausaha Baru Produksi Bahan Bangunan (Batako) Anak-anak Panti Asuhan Yatim Piatu Basa Moyudan, Sleman, Jurnal Inoteks 6(2), 2012: $175-184$.

[11] Laila, F., Pengaruh Penggunan Bottom Ash Sebagai Subtitusi Sebagian Pasir pada Paving Block, Rekyasa Teknik Sipil 1(1), 2018: 119 122.

[12] SNI-03-4142, Metode Pengujian Jumlah Bahan Dalam Agregat yang Lolos No 200, Jakarta, 1996: 6.

[13] SNI-03-1971, Metode Pengujian Kadar Air Agregat, Jakarta, 1990: 13.

[14] SNI-03-1970, Cara Uji Penyerapan dan Berat Jenis Agregat Halus, Jakarta, 2008: 18. 